\title{
Hubungan antara skor hasil bacaan heat detector dengan gambaran sitologi vagina sebagai parameter penentuan estrus pada kambing
}

\section{The relationship between heat detector reading results and the features of vaginal cytology as a parameter for determining estrus in goats}

\author{
Nanda Irsa Meydilasari'1, Tatik Hernawati ${ }^{2}$, Sri Hidanah ${ }^{3}$, Tita Damayanti \\ Lestari $^{2}$, Erma Safitri ${ }^{2}$, Trilas Sardjito ${ }^{2}$ dan Ismudiono ${ }^{2}$ \\ ${ }^{1}$ Mahasiswa, ${ }^{2}$ Departemen Reproduksi Veteriner, ${ }^{3}$ Departemen Peternakan Veteriner \\ Fakultas Kedokteran Hewan Universitas Airlangga \\ *Penulis koresponden, e-mail: Nandairsa12@gmail.com
}

\begin{abstract}
This study aimed to determine the relationship between heat detector reading results and the feature of vaginal swab preparations as a parameter for determining estrus in Peranakan Etawa goats. Five healthy non-pregnant goats weighing 20-30 kg, were synchronized using PGF2 $\alpha$ (7.5 mg Dinoprost, Enzaprost) intramuscularly twice with 11 days interval. Vaginal cytology examination began the day after the second PGF $2 \alpha$ injection. The heat detector (Draminski ${ }^{\circledR}$, Dramiński SA, Poland) is an estrus detecting device based on the amount of electric current flowing through the vaginal mucus. Spearman correlation analysis showed a relationship $(\mathrm{p}<0.05)$ between heat detector reading and estrus detection based on vaginal cytology. The heat detector readings were very significantly correlated positively $(p<0.01)$ with the number of epithelial cells (coefficient correlation, $\mathrm{r}=0.564)$, but negatively correlated with the number of cornified cells $(\mathrm{r}=-0.854)$, and also significantly correlated positively $(\mathrm{p}<0.05)$ to the number of leukocytes $(\mathrm{r}=0.487)$. The estrus stages were significantly correlated positively $(\mathrm{p}<0.05)$ only to the number of leukocytes $(\mathrm{r}=0.918)$. Likewise, the number of epithelial cells was highly correlated negatively $(\mathrm{p}<0.01)$ only to cornified cells $(r=-0,643)$, and the number of cornified cells was significantly correlated negatively $(p<0.05)$ only to the number of leukocytes $(\mathrm{r}=-0.472)$. It could be concluded that the features of the proestrus, estrus and metestrus stages based on the goat vaginal cytology was correlated with the reading results of the heat detector.
\end{abstract}

Keywords: heat detector, vaginal cytology, PGF2 $\alpha$, estrus, goat

\section{PENDAHULUAN}

Kambing peranakan Etawa (PE) merupakan salah satu kambing yang digemari masyarakat Indonesia untuk dipelihara, karena termasuk ternak dwiguna, yang dapat dimanfaatkan susu dan dagingnya. Kambing PE diketahui memiliki daya adaptasi terhadap lingkungan yang cukup tinggi, yaitu dapat bertahan pada cuaca yang relatif panas.

Pemeliharaan Kambing PE oleh petani peternak Indonesia dapat mendukung program swasembada pangan terutama dalam mencukupi kebutuhan pangan asal hewan seperti daging dan susu. Oleh karena itu diperlukan teknologi perkawinan pada kambing yang dapat memacu laju populasinya. Teknologi yang sudah dikenal di masyarakat adalah inseminasi buatan (IB). Pada penerapan IB kambing, diperlukan kemampuan deteksi birahi oleh peternak sehingga dapat diketahui waktu yang tepat untuk inseminasi yang menghasilkan kebuntingan. Masa birahi kambing antara 24-48 jam, sedangkan ovulasi terjadi 2436 jam sejak dimulainya birahi. Ketepatan waktu perkawinan merupakan faktor yang 
berperan penting untuk terjadinya kebuntingan, oleh karena itu waktu mengawinkan kambing sebaiknya dekat dengan waktu terjadinya ovulasi (Hashemi dan Safdarian, 2017). Berdasarkan hal itu diperlukan deteksi birahi yang akurat.

Heat detector (Draminski ${ }^{\circledR}$, Draminski's S.A, Polandia) diharapkan dapat membantu peternak dalam mendeteksi birahi pada kambing. Masalahnya contoh yang diberikan pada petunjuk pengoperasian alat tersebut adalah pada domba, yaitu heat detector menunjukkan angka 400 atau kurang pada masa birahi, dan lebih tinggi sampai dengan angka 600 pada masa sebelum dan sesudahnya (Draminski, 2020). Satu siklus estrus terdiri dari empat fase yaitu proestrus, estrus, metestrus dan diestrus. Setiap fase diindikasikan oleh adanya jenis sel pada mukosa vagia yang dikenal dengan gambaran sitologi vagina (Mohle et al., 2002). Perubahan komposisi sel epithel vagina tersebut terjadi akibat adanya proses hormonal selama siklus estrus.

Sehubungan dengan uraian tersebut, maka dilakukan penelitian deteksi birahi menggunakan heat detector dan korelasinya dengan fase-fase siklus birahi berdasarkan gambaran sitologi vagina.

\section{MATERI DAN METODE}

Penelitian ini menggunakan lima ekor kambing Peranakan Etawa (PE) betina dewasa yang sehat, berat badan 20-30 kg, umur 18-30 bulan, tidak bunting dan minimal paritas pertama.

Tahap pertama penelitian adalah sinkronisasi birahi pada ke lima kambing betina dengan menyuntikkan preparat PGF2 $\alpha$ (Dinoprost 7,5 mg, Enzaprost, Perancis) secara im, Penyuntikan dilakukan dua kali dengan interval 11 hari setelah penyuntikan pertama. Pengambilan data dilakukan pada hari ke 11 setelah penyuntikan pertama atau setelah penyuntikan ke dua PGF2 $\alpha$. Pembuatan preparat ulas dilakukan dengan menggunakan vaginal swab yang telah dibasahi $\mathrm{NaCL}$ fisiologis, diusapkan pada dinding vagina sehingga sel epithelnya menempel. Hasil vaginal swab diusapkan secara perlahan pada gelas objek. Selanjutnya ditetesi alkohol $70 \%$ pada gelas objek selama 1-3 menit, kemudian preparat ditetesi larutan Giemsa 1:20 selama 3-5 menit. Setelah itu preparat dikeringkan dengan cara diangin-anginkan. Preparat diamati di bawah mikroskop dengan perbesaran $40 \mathrm{x}$ (Haji et al., 2018).

Pada waktu bersamaan dengan pembuatan preparat ulas vagina dilakukan pula deteksi birahi menggunakan heat detector. Cara penggunaannya yaitu dengan memasukkan vaginal probe yang dilengkapi dengan elektroda pada ujung probe, sedalam tiga per empat bagian vagina kemudian tombol $\mathrm{ON}$ ditekan tiga kali secara berkala dan hasil pengukuran di tunggu beberapa detik hingga angka yang muncul menjadi konstan pada layar alat. Pengambilan data vagina swab dan pengukuran menggunakan heat detector dilakukan 5 hari berturut turut setelah penyuntikan PGF2 $\alpha$ kedua.

Analisis correlation spearman menggunakan SPSS 20 for Windows digunakan untuk mengetahui hubungan atau derajat keeratan korelasi antara data rasio yang memiliki skala pengukuran minimal ordinal.

\section{HASIL}

Gambaran mikroskopis hasil swab vagina berdasarkan masing-masing fase siklus birahi berdasarkan referensi adalah sebagai berikut. Pada fase proestrus terdapat dominan sel epitel normal (E), yaitu sel intermediet berbentuk polygonal, lebih besar dari pada sel lekosit dengan inti lebih kecil atau dengan sedikit sel kornifikasi (C) atau disebut juga sel superfisial, yaitu sel besar berbentuk poligonal, tanpa inti dan terjadi keratinisasi membran sel. Pada fase estrus terdapat dominan sel kornifikasi (C), fase metestrus terdapat sel epitel normal (E) dan dominan sel lekosit (L) atau disebut juga dengan sel parabasal, yaitu sel berbentuk bulat dengan inti besar; serta fase diestrus terdapat banyak sel epitel kornifikasi (C) dan lekosit (L) terkadang juga terdapat sedikit sel epitel normal (E) (Bangkit, 2013; Saputra et al., 2017). Berdasarkan kriteria tersebut fase siklus 
birahi yang terdeteksi pada kambing penyuntikan kedua PGF2 $\alpha$ dapat dilihat pada penelitian selama lima hari pengamatan setelah Tabel 1.

Tabel 1 Skor hasil bacaan heat detector, gambaran sitologi vagina dan interpretasi fase birahi pada kambing PE selama lima hari setelah penyuntikan PGF2 $\alpha$.

\begin{tabular}{|c|c|c|c|c|}
\hline $\begin{array}{l}\text { hari } \\
\text { ke- }\end{array}$ & nomor kambing & $\begin{array}{c}\text { bacaan } \\
\text { heat detector }\end{array}$ & $\begin{array}{l}\text { gambaran } \\
\text { sitologi }\end{array}$ & $\begin{array}{c}\text { fase birahi } \\
\text { berdasarkan sitologi* }\end{array}$ \\
\hline \multirow[t]{5}{*}{1} & 105 & 460 & $\mathrm{E}+++$ & proestrus \\
\hline & 324 & 200 & $\mathrm{C}+++$ & estrus \\
\hline & 125 & 400 & $\mathrm{E}++\mathrm{C}++$ & proestrus \\
\hline & G010 & 290 & $\mathrm{E}++\mathrm{C}++$ & proestrus \\
\hline & 318 & 200 & $\mathrm{E}++\mathrm{C}++$ & proestrus \\
\hline \multirow[t]{5}{*}{2} & 105 & 250 & $\mathrm{E}++\mathrm{C}++$ & proestrus \\
\hline & 324 & 190 & $\mathrm{C}+++$ & estrus \\
\hline & 125 & 340 & $\mathrm{E}++\mathrm{C}++$ & proestrus \\
\hline & G010 & 240 & $\mathrm{E}++\mathrm{C}++$ & proestrus \\
\hline & 318 & 250 & $\mathrm{E}++\mathrm{C}++$ & proestrus \\
\hline \multirow[t]{5}{*}{3} & 105 & 210 & $\mathrm{C}+++$ & estrus \\
\hline & 324 & 210 & $\mathrm{C}++$ & estrus \\
\hline & 125 & 210 & $\mathrm{C}+++$ & estrus \\
\hline & G010 & 210 & $\mathrm{C}+++$ & estrus \\
\hline & 318 & 230 & $\mathrm{C}++$ & estrus \\
\hline \multirow[t]{5}{*}{4} & 105 & 260 & $\mathrm{C}++\mathrm{L}++$ & metestrus \\
\hline & 324 & 320 & $\mathrm{C}++\mathrm{L}++$ & metestrus \\
\hline & 125 & 280 & $\mathrm{C}++\mathrm{L}++$ & metestrus \\
\hline & G010 & 290 & $\mathrm{C}++\mathrm{L}++$ & metestrus \\
\hline & 318 & 330 & $\mathrm{C}++\mathrm{L}++$ & metestrus \\
\hline \multirow[t]{5}{*}{5} & 105 & 280 & $\mathrm{C}++\mathrm{L}++$ & metestrus \\
\hline & 324 & 350 & $\mathrm{C}++\mathrm{L}++$ & metestrus \\
\hline & 125 & 260 & $\mathrm{C}++\mathrm{L}++$ & metestrus \\
\hline & G010 & 260 & $\mathrm{C}++\mathrm{L}++$ & metestrus \\
\hline & 318 & 370 & $\mathrm{C}++\mathrm{L}++$ & metestrus \\
\hline
\end{tabular}

$\mathrm{E}=$ sel epitel normal; $\mathrm{C}=$ sel kornifikasi; $\mathrm{L}=$ sel lekosit; * berdasarkan Saputra et al. (2017); heat detector Draminski ${ }^{\circledR}$ (Draminski’s S.A, Polandia).

Hasil analisis statistic (Tabel 2) menunjukkan bahwa skor hasil bacaaan heat detector sangat nyata ( $\mathrm{p}<0,01)$ berkorelasi positif terhadap jumlah sel epitel (koefisien korelasi, $r=0,564)$,namun berkorelasi negative dengan jumlah sel kornifikasi (koefisien korelasi, $\mathrm{r}=-0,854)$, serta berkorelasi positif nyata $(\mathrm{p}$ $<0,05$ ) terhadap jumlah sel lekosit (koefisien korelasi, $r=0,487$ ). Fase birahi berkorelasi positif secara nyata $(\mathrm{p}<0,05)$ hanya terhadap jumlah lekosit (koefisien korelasi, $\mathrm{r}=0,918$ ). Demikian juga jumlah sel epitel normal berkorelasi negative sangat nyata $(\mathrm{p}<0,01)$ hanya terhadap sel kornifikasi (koefisien korelasi, $r=-0,643$ ), dan jumlah sel kornifikasi berkorelasi negative secara nyata $(\mathrm{p}<0,05)$ hanya terhadap jumlah lekosit (koefisien korelasi, $\mathrm{r}=-0,472$ ).

Tabel 2 Koefisien korelasi antara skor hasil bacaan heat detector terhadap fase birahi dan sitology 
preparat usap vagina kambing PE selama liha hari setelah sinkronisasi birahi dengan PGF2 $\alpha$ secara intramuskuler.

\begin{tabular}{|c|c|c|c|c|c|}
\hline & $\begin{array}{c}\text { heat } \\
\text { detector }\end{array}$ & $\begin{array}{c}\text { fase } \\
\text { birahi }\end{array}$ & sel Epitel & $\begin{array}{c}\text { sel } \\
\text { Kornifikasi }\end{array}$ & sel Lekosit \\
\hline heat detector & 1,000 & 0,290 & $0,564 * *$ & $-0,854 * *$ & $0,487 *$ \\
\hline fase birahi & & 1,000 & $-0,379$ & $-0,288$ & $0,918 *$ \\
\hline sel Epitel & & & 1,000 & $-0,643 * *$ & $-0,231$ \\
\hline sel Kornifikasi & & & & 1,000 & $-0,472 *$ \\
\hline sel Lekosit & & & & & 1,000 \\
\hline
\end{tabular}

** korelasi sangat signifikan. $(\mathrm{p}<0,01)$; * korelasi signifikan $(\mathrm{p}<0,05)$.

\section{DISKUSI}

Hari ketiga setelah penyuntikan kedua PGF2 $\alpha$ semua kambing penelitian (100\%) mengalami birahi (Tabel 1). Hasil tersebut lebih besar daripada penelitian sebelumnya sebagai berikut. Gambaran sitologi vagina pada rusa timor dapat mendeteksi estrus sampai dengan 85\% (Nalley et al., 2011), sedangkan pada kancil dapat mendeteksi estrus mencapai $86 \%$ (Najamudin et al., 2010), dan pada anjing mendapatkan hasil 83\% (Reddy et al., 2011).

Angka yang rendah pada hasil bacaan Heat Detector menunjukkan kambing sedang birahi, sedangkan angka yang lebih tinggi menunjukkan fase sebelum birahi (proestrus) atau sesudah birahi (metestrus dan diestrus) (Draminski, 2020). Pada penelitian ini kambing yang terdeteksi pada fase proestrus, estrus, dan metestrus berdasarkan pemeriksaan swab vagina menunjukkan angka bacaan hasil Heat Detector secara berurutan adalah antara 190 - 230, proestrus antara $200-$ 460, dan metestrus antara $260-370$.

Gambaran sitologi vagina kambing PE pada penelitian ini menunjukkan kecenderungan bahwa ketika jumlah sel-sel epitel normal menurun, diikuti oleh jumlah sel-sel epitel kornifikasi meningkat. Demikian juga ketika jumlah jumlah sel kornifikasi menurun, diikuti meningkatnya jumlah sel-sel lekosit (Tabel 2). Hal ini disebabkan karena dinamika perubahan sel-sel epitel vagina dipengaruhi oleh dinamika endokrin selama dalam siklus birahi. Kambing penelitian sebelum disuntik dengan PGF2 $\alpha$ diasumsikan dalam fase luteal, yaitu terdapat korpus luteum yang menghasilkan hormon progesteron. Kadar hormon progesteron yang dominan selama fase luteal menyebabkan negative feedback, yaitu hipofisa anterior tidak mensekresikan Follicle Stimulating Hormon (FSH). Penyuntikan PGF2 $\alpha$ menyebabkan regresi korpus luteum, sehingga kadar progesteron dalam darah menurun drastis menjadi basal. Rendahnya kadar progesteron diikuti hilangnya negative feedback sehingga FSH disekresikan yang menyebabkan pertumbuhan folikel. Ketika dalam folikel sudah terbentuk antrum folliculi maka folikel tersebut mulai menghasilkan hormon estrogen. Hormon estrogen menyebabkan perkembangan sel-sel epitel berinti (epitel normal) yang menandai fase proestrus. Ketika folikel telah mencapai stadium follicle de Graaf, hormon estrogen juga mencapai kadar puncaknya yang menimbulkan tanda-tanda birahi. Seiring dengan perjalanan waktu dan meningkatnya kadar hormon estrogen, maka selsel epitel berinti berubah menjadi sel epitel tidak berinti dan mengalami kornifikasi pada membran selnya. Kadar estrogen yang mencapai puncaknya pada saat birahi memicu hipofisa anterior untuk melepaskan Luetinizing Hormon (LH) yang menyebabkan terjadinya ovulasi. Setelah ovulasi, kadar hormon estrogen menurun drastic, sel-sel pada jaringan sisa ovulasi mengalami luteinasi membentuk korpus luteum yang menghasilkan hormon progesteron, dan menyebabkan dimulainya infiltrasi sel-sel lekosit ke dalam vagina (Jainudeen et al., 2000; Lestari, 2014).

Heat detector bekerja berdasarkan adanya 
hambatan arus listrik pada lendir vagina sebagai indikatornya (Fitria et al. (2018). Pada saat estrogen yang tinggi mempengaruhi vasodilatasi vagina sehingga terjadi peningkatan volume lendir serviks yang disekresikan oleh sel-sel goblet, dimana lendir serviks memiliki konduktifitas yang relatif tinggi sehingga semakin banyak lendir serviks maka daya hambatan listrik semakin rendah (Verma et al., 2014). Daya hambat listrik semakin rendah artinya nilai yang muncul pada layar alat heat detector menunjukan angka yang kecil berkisar antara 190 sampai 230. Angka yang ditampilkan pada layar alat heat detector tersebut menunjukan bahwa lendir yang dihasilkan memiliki volume yang relatif banyak sehingga kadar hormon estrogen dalam darah juga mengalami peningkatan, maka kambing tersebut mengalami fase estrus.

\section{KESIMPULAN}

Gambaran fase proestrus, estrus dan diestrus berdasarkan sitologi swab vagina kambing PE berkorelasi dengan nilai hasil pembacaan heat detector.

\section{DAFTAR PUSTAKA}

Bangkit AF. 2013. Penentuan estrus melalui gambaran sitologi ulas vagina dan hubungannya dengan gejala klinis estrus pada kambing Peranakan Etawah. Skripsi, Fakultas Kedokteran Hewan, Istitut Pertanian Bogor.

Draminski, 2020. Estrous detector for sheep and goats Ed 2. https://www.draminski.com/agri/estrousdetectors/draminski-eds-2-estrous-detectorfor-sheep-and-goats/, 5 Mei 2020.

Fitria, NY, Wayan NKK, Agus MS. 2018. Karakteristik dan respons estrus domba setelah pemberian progesterone-controlled internal drug release selama 12 dan 13 hari. J Veteriner 19: 502-11.

Haji, M, Ahmed FA, Lalrintluanga K, Talukdar DJ, Doley PJ, Bahera SK, Sarma K. 2018. The role of estrogen and progesterone hormone on vaginal cytology in bitch. Int $\mathbf{J}$ Livest Res. 8: 241-47.
Hashemi M, Safdarian M. 2017. Efficiency of different methods of estrus synchronization followed by fixed-time artificial insemination in Persian downy does. Anim Reprod 14:.4137.

Jainudeen MR, Wahid H, Hafez ESE. 2000. Sheep and goats. In: Reproduction in Farm Animals. 7th. Edition. Eds: B Hafez and ESE. Hafez. Lippincott Williams \& Wilkins. Baltimore. 2-181.

Lestari TD. 2014. Ilmu Reproduksi Ternak. AUP. Universitas Airlangga Surabaya.

Mohle U, Heistermann M, Pahme R, Hodges JK. 2002. Characterization of urinary and fecal metabolite of testosterone and their measurement for assessing gonadal endocrine function in male nonhuman primates. Gen Comp Endocr. 129: 135-45.

Najamuddin, Rusdin, Sriyanto, Amrozi, S. Agungpriyono S, Yusuf TL. 2010. Penentuan siklus estrus pada kancil (Tragulus javanicus) berdasarkan perubahan sitologi vagina. J Veteriner 11: 81-6.

Nalley WMM, Handarini R, Rizal M, Arifiantini RI, Yusuf TL, Purwantara B. 2011. Penentuan siklus estrus berdasarkan gambaran sitologi vagina dan profil hormon pada rusa timor. J Veteriner 12: 98-106.

Reddy KCS, Raju KGS, Rao KS, Rao KBR. 2011. Vaginal cytology, vaginoscopy and progesterone profile: breeding tools in bitches. Iraqi J Vet Sci. 25: 51-4.

Saputra D, Sumartono S, Humaidah N. 2017. Hubungan kualitas estrus berdasarkan profil sitologi swab vagina dan gejala estrus terhadap keberhasilan IB intracervical kambing peranakan etawa. Dinamika Rekasatwa 2: 1-9.

Verma KK, Prasad S, Kumaresan A, Mohanty TK, Layek SS, Patbandha TK, Chand S. 2014. Characterization of physic-chemical properties of cervical mucus in relation to parity and conception rate in Murrah buffaloes. Vet World 7: 467-71. 